\title{
MENAKAR TATA KELOLA EKONOMI DESA: OTOKRITIK TERHADAP KEBIJAKAN PEMBERDAYAAN EKONOMI PERDESAAN
}

\author{
Suryanto, S.Sos, M.Si \\ Lembaga Administrasi Negara \\ Widhi Novianto, S.Sos, M.Si \\ Lembaga Administrasi Negara
}

\begin{abstract}
Abstrak
Desa dan kemiskinan merupakan dua kata yang hampir tidak terpisahkan. Hal ini karena desa dan masyarakat desa relatif jauh dari sumber-sumber ekonomi dan faktor-faktor produksi. Untuk mengatasi kelemahan tersebut, warga masyarakat berusaha mengatasi kemiskinan mereka dengan berbagai upaya, di antaranya melalui urbanisasi dan migrasi ke tempat lain. Dengan maksud yang sama, Pemerintah telah menginisiasi program-program pemberdayaan ekonomi desa seperti Inpres Desa Tertinggal (IDT), Program Nasional Pemberdayaan Masyarakat Mandiri Perdesaan (PNPM-MP), dan seterusnya. Terakhir, melalui UU Desa, Pemerintah menginisiasi pembentukan Badan Usaha Milik Desa (BUM Desa). Tulisan ini bertujuan memberikan masukan tentang pengelolaan tata kelola ekonomi desa, dengan memberikan kritik terhadap kebijakan BUM Desa. Metode yang digunakan dalam penulisan ini adalah metode kualitatif, dengan melakukan analisis kritis permasalahan dengan memanfaatkan data dan informasi baik yang berasal dari berbagai referensi maupun hasil kajian sebelumnya. Disain tata kelola ekonomi desa dan perdesaan yang ditawarkan adalah mereplikasi program pemberdayaan ekonomi yang dianggap sudah berhasil atau memberdayakan lembaga BUM Desa dengan cara membentuk BUM Desa sesuai kebutuhan, membentuk BUM Desa Bersama untuk membangkitkan ekonomi perdesaan, dan menghindari BUM Desa sebagai predator bagi usaha rakyat yang sudah berkembang.
\end{abstract}

Kata kunci: desa, pemberdayaan ekonomi, tata kelola.

\section{Abstract}

Village and poverty are two words that are almost inseparable, this is because villages and villagers are relatively far from economic sources and factors of production. To overcome these weaknesses, villagers often try to overcome their poverty through various efforts, including urbanization and migration to other places. Likewise, to overcome poverty, Government has initiated village economic empowerment programs such as Inpres Desa Tertingal (IDT)-specific measures for disadvantage villages, National Program for Rural Community Empowerment (PNPM-MP), and so forth. Recently, through the Village Law, the Government initiated the formation of Village Owned Enterprises (BUM Desa). This article aims to provide input to the management of village economic governance, by providing criticism of the BUM Desa policy. The method used in this paper is a qualitative method, through critical analysis of problems by utilizing data and information, derived from the references and the results of previous studies. This article recommends a design of village economic and rural governance through replicating the economic empowerment programs that are considered successful or through empowering the BUM Desa institutions by establishing BUM Desa as needed, establishing BUM Desa Bersama to develop rural economy, and preventing BUM Desa from being a predator to established villager's enterprises.

Keywords: village, economic empowerment, governance. 


\section{Pendahuluan}

Dalam buku lama berjudul "Urbanisasi dan Kemiskinan" Gilbert \& Gugler (1996: 60) mempertanyakan mengapa masyarakat berpindah (berurbanisasi)? Jawabannya karena alasan ekonomi. Sebuah badan penelitian tentang migrasi desa-kota terkemuka setelah mengadakan penelitian selama dua dekade menemukan banyak bukti bahwa mayoritas penduduk berpindah karena alasan ekonomi. Argumentasi semacam ini mengindikasikan bahwa tingkat ekonomi perdesaan relatif berada di bawah tingkat ekonomi perkotaan. Walaupun sesungguhnya indikator tersebut tidaklah selalu benar karena dengan tingkat upah yang lebih baik di perkotaan, hal itu belum sepenuhnya menjamin kesejahteraan masyarakat perkotaan. Hal ini terlihat dari maraknya permukiman penduduk perkotaan yang banyak diwarnai dengan kekumuhan, kemiskinan, dan sebagainya.

Sampai saat ini persoalan hubungan desa-kota dalam konteks ekonomi dapat dikatakan masih menjadi persoalan krusial dalam wacana pemberdayaan ekonomi desa. Adisasmita (2006: 68), mencatat permasalahan dan tantangan pengembangan ekonomi desa, meliputi: (1) belum meratanya distribusi faktor produksi dan prasarana (fisik dan nonfisik) ke seluruh desa, (2) masih terdapatnya desa dan kawasan desa yang tertinggal akibat manajemen pembangunan yang cenderung berorientasi pada sentralisasi dan adanya konsentrasi pertumbuhan ekonomi di pusatpusat daerah persediaan yang maju, (3) belum optimalnya pemanfaatan potensi ekonomi desa yang bertumpu pada keunggulan geografis dan sumber daya intelektual lokal sebagai basis ekonomi dalam pembangunan desa, dan (4) belum optimalnya keterlibatan masyarakat secara aktif dalam proses pembangunan desa.

Artikel ini akan menganalisis atau mengevaluasi tata kelola ekonomi perdesaan yang telah ada dan dilaksanakan sejak masa orde baru sampai dengan sekarang, khususnya di era UU No. 6
Tahun 2014 tentang Desa. Selanjutnya, dengan berlandaskan pada pengalaman empiris pada masa lalu dan yang berkembang saat ini serta berdasarkan konsep/teori yang relevan, penulis mencoba mengusulkan desain tata kelola ekonomi perdesaan yang selaras dengan amanat Undang-Undang Desa melalui pemberdayaan BUM Desa.

Pertanyaan pokok artikel ini adalah: 1) Bagaimana tata kelola ekonomi perdesaan yang telah berlaku di Indonesia sejak dulu hingga saat ini?; 2) Bagaimana upaya menjadikan BUM Desa menjadi salah satu alternatif dalam membangun tata kelola ekonomi perdesaan di Indonesia?

Persoalan tata kelola ekonomi perdesaan ini menjadi penting, terutama sejak lahirnya UU No. 6 Tahun 2014 tentang Desa, PP No. 43 Tahun 2014 tentang Peraturan Pelaksanaan UU No. 6 Tahun 2014 tentang Desa, PP No. 60 Tahun 2014 tentang Dana Desa yang Bersumber dari APBN, dan Permendesa PDTT No. 4 Tahun 2015 tentang BUM Desa.

BUM Desa diharapkan menjadi pilar ekonomi desa dan perdesaan (Yunanto, 2014: 3-4). Dalam policy paper Forum Pengembangan Pembaharuan Desa (FPPD) menjelaskan kelemahankelemahan BUM Desa, antara lain:

1. Penataan kelembagaan desa belum berjalan secara maksimal sehingga BUM Desa pun belum dilembagakan dalam format kepemerintahan dan perekonomian desa.

2. Keterbatasan kapasitas sumber daya manusia di desa untuk mengelola dan mengembangkan BUM Desa yang akuntabel dan berkinerja baik.

3. Rendahnya inisiatif lokal untuk menggerakkan potensi ekonomi lokal bagi peningkatan kesejahteraan sosial dan ekonomi warga desa.

4. Belum berkembangnya proses konsolidasi dan kerjasama antar pihak terkait untuk mewujudkan BUM Desa sebagai patron ekonomi yang berperan memajukan ekonomi kerakyatan. 
5. Kurangnya responsivitas Pemda untuk menjadikan BUM Desa sebagai program unggulan untuk memberdayakan desa dan kesejahteraan masyarakat.

Bapermas Kabupaten Banyumas (2016) misalnya, mencatat sejumlah pointer yang layak menjadi catatan BUM Desa:

1. Badan hukum BUM Desa. Pasal 4 ayat 1 Permendesa PDTT No. 4 Tahun 2014 menyatakan secara jelas bahwa dasar pendirian BUM Desa adalah Peraturan Desa. Bahwa ada sebagian BUM Desa di Kabupaten Banyumas yang diarahkan untuk membuat akta notaris itu kurang tepat karena di dalam Permendesa PDTT tersebut tidak ada kewajiban seperti itu. Kemungkinan yang menjadi kesalahan persepsi selama ini adalah unit usaha yang dinaungi oleh BUM Desa boleh berbadan hukum. Hal itu sejalan dengan Permendesa PDTT No 4 Tahun 2015, pasal 8 yang menyatakan bahwa unit usaha BUM Desa dapat berupa Perseroan Terbatas dan Lembaga Keuangan Mikro yang notabene-nya berbadan hukum.

2. BUM Desa akan memonopoli usaha di desa yang sudah ada. Hal tersebut dapat memunculkan berbagai pertanyaan. Apakah dengan adanya BUM Desa lantas secara otomatis usaha-usaha yang ada di desa harus bergabung dan berada di bawah naungan BUM Desa tersebut? Unit usaha yang telah ada terlebih dahulu sebelum pembentukan BUM Desa dapat bergabung ataupun tidak. Hal tersebut tergantung dari kesepakatan pengelola unit usaha tersebut. Tidak ada paksaan untuk menggabungkan unit usaha di bawah pengelolaan BUM Desa.

3. Bagaimana cara memulai usaha bagi BUM Desa yang baru? Pertimbangan yang dijadikan dasar pendirian BUM Desa diantaranya adalah: potensi usaha ekonomi desa, sumber daya alam desa dan sumber daya manusia yang mengelola BUM Desa tersebut. Untuk BUM Desa baru yang belum memiliki unit usaha diharapkan mampu untuk menggali potensi usaha ekonomi berdasarkan sumber daya alam dan manusia di desanya masing-masing. Oleh karena itu diperlukan pendampingan yang lebih intensif bagi BUM Desa baru yang ingin mewujudkan potensi ekonomi dan sumber daya alam agar mampu menggerakkan perekonomian masyarakat desa. Lantas siapa yang bertugas melakukan pendampingan?

Dari kajian atau telaahan mengenai BUM Desa terdahulu, penulis bermaksud mempertajam apa yang ditelaah oleh Yunanto (FPPD) maupun apa yang ditelaah oleh Bapermas Kabupaten Banyumas, Jawa Tengah. Selain mempertajam pendapat kajian terdahulu, penulis juga mengupas aspek yang relatif baru terkait dengan evaluasi tata kelola ekonomi perdesaan.

\section{Konsep Tata Kelola}

Sebelum menjelaskan lebih jauh mengenai konsep tata kelola dan seterusnya, terlebih dahulu akan dijelaskan makna "menakar". Dalam Kamus Besar Bahasa Indonesia (KBBI), menakar/me.na.kar/ $\quad v \quad \mathbf{1}$ mengukur banyaknya barang cair, beras, dan sebagainya: minyak dengan literan; 2 membatasi jumlah: kita harus $\sim$ jatah mereka dengan adil.

Selanjutnya terkait dengan konsep tata kelola (governance) yang digunakan, hal ini didasarkan pada kenyataan bahwa meskipun selama ini telah dikenal berbagai program/kegiatan ekonomi perdesaan, namun semua itu dapat dikatakan belum sepenuhnya dikelola dengan baik.

Sebagai contoh, pelaksanaan program IDT di masa orde baru, mungkin program ini akan lebih dirasakan manfaatnya oleh masyarakat perdesaan apabila diterapkan tata kelola pembangunan ekonomi perdesaan secara terintegrasi. Demikian pula, pelaksanaan 
program PNPM Mandiri Perdesaan, pun belum sepenuhnya dikelola secara optimal. Apabila BUM Desa akan dijadikan salah satu pilar ekonomi perdesaan sebagaimana ditulis oleh Yunanto dkk. (2014) dari FPPD - maka urgensi 'tata kelola' ini menjadi sangat relevan. Fakta bahwa BUM Desa Tirta Mandiri-Desa Ponggok, Klaten dapat membiayai iuran bulanan BPJS mandiri sebanyak 800 warga masyarakat Desa Ponggok merupakan bukti bahwa tata kelola merupakan hal yang krusial dalam pembangunan ekonomi desa dan perdesaan.

Dixit (2001: 4) menyatakan bahwa tata kelola perekonomian terdiri dari proses yang mendukung aktivitas ekonomi dan transaksi ekonomi dengan melindungi hakhak kepemilikan, melaksanakan kontrak, dan bersama-sama bekerja untuk menghasilkan infrastruktur fisik dan keorganisasian yang tepat. Selanjutnya, Kong (2011: 3) secara sederhana mendefinisikan kualitas tata kelola sebagai kapasitas pemerintah untuk menginternalisasi eksternalitas. Walaupun definisi Dixit dan Tong masih bersifat umum, mereka memberikan permulaan yang sangat berguna untuk menelusuri pemahaman yang lebih dalam.

Beberapa ahli lebih menyempitkan pola pandangannya dengan menguraikan tata kelola menjadi konsep yang terpisah, seperti korupsi (Wei, 2000: 318), transparansi (Kaufmann et al., 2000: 12), peraturan (Djankov et al., 2002: 1), dan pengadaan barang publik (Kaufmann et al., 2005: 9), yang mana setiap mereka masih mengandung banyak jenis dan pencetus kebijakan interaksi yang berbeda. Ahli-ahli lain melihat dari sudut pandang mikro di mana kebijakan individu seperti prosedur registrasi bisnis telah dipisahkan dan dilakukan secara terpisah dari tata kelola lain dalam masyarakat (lihat: contohnya Helpman (2008: 12) untuk beberapa kajian terkini).

Berdasarkan beberapa penjelasan di atas, satu hal penting yang dapat disimpulkan adalah kemampuan pemerintah mengelola urusan administrasinya akan membawa dampak yang sangat kuat pada aktifitas pelaku ekonomi. Walaupun konsep tata kelola tidaklah baru, konsep tersebut sama tuanya dengan peradaban manusia. Namun sayangnya, faktor ini dianggap telah ada pada model pertumbuhan ekonomi neoklasik tradisional, seperti apa yang telah diungkapkan Solow (1996), Cass (1965), dan Koopmans (1965).

Inovasi teknologi hanya dapat diciptakan karena lingkungan institusional. Benang merah antara institusi, pemerintahan, dan kinerja ekonomi telah menjadi subyek yang sangat sering didiskusikan selama 25 tahun terakhir. Apa yang telah dilakukan North (1981) dalam Kuncoro (2012) dapat dianggap sebagai pionir ide yang berkembang tentang pemicu kapabilitas pemerintah. Menurut North (1981), institusi/lembaga merupakan aturan main masyarakat atau, secara formal, kendala-kendala/batasan-batasan yang terjadi secara manusiawi yang membentuk interaksi manusia. Kendala/ batasan tesebut akan berpengaruh melalui sebuah dorongan (North, 1990). Dorongan yang dimaksudkan di sini adalah mengkondisikan kesediaan pelaku ekonomi untuk menerima aturan main tersebut.

Oleh karenanya, banyak ahli ekonomi mengembangkan ide North dalam menciptakan sebuah dorongan bagi pertumbuhan ekonomi dengan menggunakan perspektif yang berbeda. Inti tujuannya sama, seperti mengurangi ketidakpastian dan mendorong efisiensi. Ekonomi politik baru (new political economy), contohnya, membantah pentingnya program-program penyesuaian struktur dengan menghilangkan motif rent seeking dan korupsi (Krueger, 1974; Posner, 1975; Bhagwati, 1982; Bardhan, 1984; Colander, 1984; Alt dan Shepsle, 1990; Lal dan Myint, 1996; Bates, 2001).

Sejalan dengan Ekonomi Politik Baru, Lembaga Ekonomi Baru (dicetuskan oleh Williamson, 1975; 1985) telah menyatakan teori ekonomi yang 
mengidentifikasi kemampuan tata kelola yang harus dimiliki oleh negara demi terciptanya efisiensi pasar. Intinya adalah Lembaga Ekonomi Baru menekankan pentingnya market-enhancing government melalui perlindungan pelaksanaan kontrak dan hak kepemilikan. Singkatnya, Acemoglu, Hohnson, dan Robinson (2005) menyimpulkan bahwa tata kelola pemerintah yang baik merupakan dasar utama dari pertumbuhan ekonomi. Walaupun tidak ada sebuah tata kelola tanpa pemerintah, tata kelola tidak bisa semata-mata dipandang sebagai hasil tapi juga sebagai serangkaian hubungan dan proses yang menghasilkan.

Bank Dunia (2005:24) telah menyimpulkan enam indikator tata kelola secara luas: 1) Suara dan Akuntabilitas menilai hak-hak politik, sipil, dan manusia, 2) Ketidakstabilan Politik dan Kekerasan mengukur tingkat kemungkinan adanya ancaman kekerasan terhadap, atau perubahan pada, pemerintah, termasuk terorisme, 3) Efektivitas Pemerintah mengukur kompetensi birokrasi dan kualitas pelayanan masyarakat, 4) Beban Peraturan - mengukur sejauh mana dampak dari kebijakan pasar yang tidak bersahabat, 5) Peraturan Hukum - mengukur kualitas pelaksanaan kontrak, polisi, dan pengadilan, serta kemungkinan adanya kriminalitas dan kekerasan, dan 6) Kontrol Korupsi - mengukur sejauh mana kekuatan publik atas keuntungan pribadi, termasuk korupsi skala besar dan kecil serta state capture.

Enam indikator di atas menunjukkan bahwa kualitas tata kelola merupakan penjabaran yang cukup rumit. Bentuknya dapat bermacam-macam dan kemungkinan adanya trade-off antara dimensi tata kelola yang berbeda. Kong (2011: 3) mengemukakan bahwa tata kelola yang baik sering dimaknai sebagai pemerintahan yang efektif, yakni merupakan konsep yang multidimensional dan luas. Berbagai macam indikator tata kelola yang telah banyak digunakan tidak mencakup seluruh ide dari tata kelola tersebut. Thomas
(2007:11) mengemu-kakan indikatorindikator tersebut merupakan hasil dari penggabungan gagasan-gagasan mengenai tata kelola yang diajukan oleh penggagasnya.

Terlepas dari dimensi tata kelola yang berbeda, titik temu dari seluruh pandangan tersebut menghasilkan rangkaian prioritas kebijakan yang kita kenal sebagai agenda tata kelola yang baik. Studi empiris yang berkaitan dengan tata kelola (ekonomi) yang baik telah berjalan secara luas.

\section{Menakar Pemberdayaan Ekonomi Desa dan Perdesaan dari Masa Ke Masa}

Pada masa lalu, hadirnya program pemberdayaan masyarakat seperti Inpres Desa Tertinggal (IDT) berdasarkan Inpres Nomor 5 Tahun 1993, tanggal 27 Desember 1993 menjadi salah satu pengungkit dalam upaya pemberdayaan ekonomi desa. Kartasasmita (1994:1) menyatakan bahwa Program IDT mengandung 3 pengertian dasar, yaitu (1) sebagai pemicu gerakan nasional penanggulangan kemiskinan, (2) sebagai strategi dalam pemerataan pembangunan, dan (3) sebagai upaya pengembangan ekonomi rakyat melalui pemberian bantuan dana bergulir untuk modal usaha bagi penduduk miskin. Mekanisme pelaksanaan program ini adalah melalui pemberian bantuan berupa sejumlah dana bergulir dan bantuan hewan ternak (sapi dan kambing) kepada masyarakat desa yang ada di kategori miskin. Uang dan ternak yang diberikan oleh pemerintah berfungsi sebagai pemberdayaan (empowerment) masyarakat, yakni dengan menempatkannya sebagai modal awal untuk menghasilkan laba di masa-masa yang akan datang.

Selain Program IDT, di masa orde baru juga dikenal program pemberdayaan ekonomi masyarakat desa yakni Tabungan Keluarga Sejahtera (Takesra) dan Kredit Usaha Keluarga Sejahtera (Kukesra). Program Takesra dan Kukesra dilaksanakan berdasarkan Inpres Nomor 3 Tahun 1996. Menurut Masrikhin (2001: 
121), mekanisme pelaksanaan program ini adalah dengan penyaluran kredit kepada keluarga-keluarga miskin di pedesaan, yang ditekankan pada para wanita peserta akseptor KB. Senada dengan program IDT, program ini pun menempatkan masyarakat desa sebagai obyek program sehingga "pemberdayaan" yang diharapkan tidak pernah tercapai dengan optimal.

Pada era reformasi, Pemerintah meluncurkan Program Nasional Pemberdayaan Mandiri Masyarakat Desa (PNPM-MD) berdasarkan Keputusan Menteri Koordinator Bidang Kesejahteraan Rakyat Nomor 25/KEP/MENKO/KESRA/ VII/2007Tentang Pedoman Umum PNPMMANDIRI DESA. PNPM Mandiri Desa diresmikan oleh Presiden Republik Indonesia (SBY) pada tanggal 30 April 2007 di Kota Palu-Provinsi Sulawesi Tengah.

PNPM Mandiri terbagi menjadi PNPM Mandiri Perkotaan dan PNPM Mandiri Desa. PNPM Mandiri Desa/Rural PNPM adalah mekanisme program pemberdayaan masyarakat yang digunakan oleh PNPM Mandiri dalam rangka mempercepat penanggulangan kemiskinan yang terjadi dan juga perluasan kesempatan kerja di wilayah-wilayah desa. Secara historis, PNPM Mandiri Desa juga mengadopsi sepenuhnya mekanisme dan prosedur Program Pengembangan Kecamatan (PPK) yang sudah dilaksanakan sejak tahun 1998.

Upaya peningkatan kesejahteraan masyarakat desa juga dilakukan secara individu/perorangan dengan melakukan migrasi, baik migrasi secara permanen ke perkotaan (urbanisasi), migrasi ulang-alik, maupun migrasi secara berkala (sirkuler). Menurut Todaro (2004, dalam Wibawa, 2011), migrasi adalah suatu proses perpindahan sumber daya manusia dari tempat-tempat yang produk marjinal sosialnya nol ke lokasi lain yang produk marjin sosialnya bukan hanya positif, tetapi juga akan terus meningkat sehubungan dengan adanya akumulasi modal dan kemajuan teknologi. Menurut Supadmo
(1991) dalam Wibawa (2011) yang dimaksudkan mobilitas sirkuler adalah penduduk yang bekerja di luar wilayah desanya dan pulang kembali setelah minimal dua hari dan maksimal enam bulan baik secara teratur maupun tidak. Batas waktu minimal dua hari untuk membedakan dengan mobilitas ulang-alik dan batas waktu maksimal enam bulan untuk membedakan dengan migran menetap.

Selanjutnya, dalam upaya meningkatkan kesejahtaraan, sebagian masyarakat di desa juga mengadu nasib ke negeri orang dengan menjadi buruh migran. Menurut Departemen Sosial (saat ini Kementerian Sosial), definisi buruh migran adalah orang yang berpindah ke daerah lain, baik di dalam maupun ke luar negeri (legal maupun ilegal), untuk bekerja dalam jangka waktu tertentu. Sedangkan menurut Wickramasekera (2002: 1), mengacu kepada Konvensi ILO pada Buruh Migran tahun 1949, (No.97) pada Article 11, adalah orang yang bermigrasi dari satu negara ke negara lain untuk tujuan bekerja.

Beberapa negara tujuan TKI/TKW adalah Arab Saudi, Hongkong, Taiwan, Malaysia, dan sebagainya. Cara ini tetap ditempuh oleh sebagian masyarakat desa, meskipun sering terjadi permasalahan yang menimpa buruh migran seperti kekerasan, penyalahgunaan/ penyimpangan, pemalsuan dokumen, dan pemberian informasi yang salah.

Buruh migran memiliki posisi yang penting karena mereka telah memberikan sumbangan berupa devisa atau remittances. Buruh migran memberikan remmitance yang tidak sedikit, yaitu antara 1 sampai 6 juta USD kali per tahun dengan total jumlah per transaksi sekitar 200-500 ribu USD. Remittances memiliki beberapa urgensi: (1) bagi banyak keluarga digunakan untuk kebutuhan sehari-hari, untuk pendidikan, pengembangan rumah, membeli tanah, membayar hutang, dan memulai bisnis; (2) bagi masyarakat lokal keuntungan dari remittances melalui efek trickle down effect; (3) bagi Indonesia, remittances 
menyumbang 1,6\% dari GDP (Gross Domestic Product - Produk Domestik Bruto).

Pada era reformasi jilid II, Pemerintah menerbitkan Undang-Undang Nomor 6 Tahun 2014 tentang Desa yang memberikan payung hukum dalam memajukan perekonomian desa. Dalam implementasinya, Undang-Undang Desa memiliki beberapa tujuan utama meliputi: 1) pengakuan dan status hukum pada sistem pemerintahan setingkat desa yang beragam di Indonesia; 2) mendorong tradisi dan kebudayaan masyarakat; 3) mendorong partisipasi warga dalam pemerintahan desanya; 4) meningkatkan pelayanan untuk semua orang lewat lebih sanggupnya pemerintahan desa; dan 5) mendorong pembangunan desa oleh warganya sendiri (prinsip partisipatif).

Selanjutnya sebagai pelaksanaan UU Desa telah diterbitkan PP Nomor 60 Tahun 2014 tentang Dana Desa. Peraturan ini menegaskan bahwa desa yang sudah siap membangun, perlu dukungan dana. Artinya, dana desa diadakan dengan dua cita-cita yakni pertama, agar pemerintah desa lebih mampu melayani kebutuhan warga dan kedua, menumbuhkan inisiatif warga desa secara lebih aktif dalam membangun desanya.

\section{BUM Desa dan Harapan Keberhasilan Pemberdayaan Ekonomi Desa}

BUM Desa pada dasarnya merupakan pilar kegiatan ekonomi di desa yang berfungsi sebagai lembaga sosial (social institution) dan lembaga komersial (commercial institution). Sebagai lembaga komersial, BUM Desa menjadi salah satu program strategis pemerintah dalam upaya meningkatkan kesejahteraan ekonomi masyarakat di desa. Sementara sebagai lembaga sosial, BUM Desa harus berpihak kepada kepentingan masyarakat melalui kontribusinya dalam penyediaan pelayanan sosial.

Sejumlah BUM Desa yang dianggap sukses seperti BUM Desa Tirta Mandiri di Desa Ponggok, Polanharjo-
Klaten dan BUM Desa Panggung Lestari di Desa Panggungharjo, Sewon-Bantul adalah contoh bagaimana pemerintahan desa memiliki visi-misi memajukan ekonomi desa mereka. BUM Desa Tirta Mandiri berhasil membangun usaha wisata kolam renang, perikanan, pembinaan PKL, penyediaan air bersih, jasa konstruksi, hingga pengadaan barang dan jasa. Sementara BUM Desa Panggung Lestari berhasil membangun usaha pengelolaan sampah dan terus mengembangkan usahanya dengan menggandeng mitramitra strategis yang mereka miliki (lihat Tabel 1).

Pertanyaannya adalah apakah BUM Desa yang telah diterapkan merupakan manifestasi tata kelola ekonomi desa menuju masyarakat desa sejahtera? Undang-Undang Desa mengkonstruksikan Desa sebagai organisasi campuran (hybrid) antara masyarakat berpemerintahan (self governing community) dengan pemerintahan lokal (local self government, di mana desa memiliki otonomi dan kewenangan dalam perencanaan, pelayanan publik, dan keuangan. Maka desa bukan lagi penunggu instruksi dari supra desa (Kecamatan, Kabupaten, Provinsi, dan Pusat). Untuk itu tumpuan dinamika kehidupan desa sangat bergantung pada partisipasi masyarakat dalam mendorong terbangunnya kesepakatan pengelolaan desa, mampu menumbuhkan dan mengembangkan nilai sosial, budaya, ekonomi, dan pengetahuan. Pembangunan desa dapat ditingkatkan melalui pengembangan potensi perekonomian desa dan menjadi wadah bersama masyarakat pedesaan dalam membangun diri dan lingkungannya secara mandiri dan partisipatif. Dalam UU Desa disebutkan bahwa pembangunan desa bertujuan untuk meningkatkan kualitas hidup manusia serta penanggulangan kemiskinan, melalui penyediaan pemenuhan kebutuhan dasar, pembangunan sarana dan prasarana, pengembangan potensi ekonomi lokal, serta pemanfaatan 
sumber daya alam dan lingkungan secara berkelanjutan, dengan mengedepankan kebersamaan, kekeluargaan, dan kegotongroyongan guna mewujudkan pengarusutamaan perdamaian dan keadilan sosial.

Dalam rangka mengembangkan potensi ekonomi desa dan meningkatkan kesejahteraan masyarakat, dalam pasal 87 UU tersebut menyatakan bahwa pemerintah desa dapat membentuk BUM Desa. Kelembagaan BUM Desa diharapkan dapat memberikan ruang pengambilan peran negara melalui Pemerintah Desa untuk mengelola sumber daya alam yang dimiliki desa dan bidang produksi yang penting bagi desa dan yang menguasai hajat hidup warga desa.

Selanjutnya, dalam rangka pelaksanaan UU Desa telah dibuat aturan turunannya antara lain Peraturan Pemerintah Nomor 43 Tahun 2014 jo Peraturan Pemerintah Nomor 47 Tahun 2015 sebagai peraturan pelaksanaan undang-undang tersebut yang kemudian secara khusus BUM Desa dipayungi dan digerakkan dalam Peraturan Menteri Desa, PDT dan Transmigrasi Nomor 4 Tahun 2015 tentang Pendirian, Pengurusan dan Pengelolaan dan Pembubaran Badan Usaha Milik Desa.

Sebelum hadir Peraturan Peraturan Menteri Nomor 4 Tahun 2015, sebagian daerah telah membentuk BUM Desa, dan pasca Peraturan Menteri Desa tersebut maka semakin banyak BUM Desa yang terbentuk. Hingga saat ini telah terbentuk 12.115 BUM Desa seperti dilansir dari situs resmi Kementerian Desa PDTT. Jumlah tersebut melampaui target sebanyak 5.000 BUM Desa pada tahun 2019 yang telah mereka tetapkan dalam Nawa Kerja Kementerian Desa dan Pembangunan Daerah Tertinggal dan Transmigrasi. Namun hingga saat ini belum ada data yang menunjukkan kinerja BUM Desa yang sudah terbentuk.

Pencapaian yang melampaui target tersebut, menimbulkan kerisauan yang tertuju pada keberlanjutan BUM Desa secara sosial dan ekonomi yang saat ini tengah menjamur di berbagai desa. Ada kerisauan, jangan-jangan BUM Desa akan mati suri pada tahun-tahun mendatang seperti halnya BUUD maupun KUD yang dibangun secara seragam oleh Orde Baru. Keberlanjutan BUM Desa di satu sisi dan kegagalan BUUD dan KUD di sisi lain tentu merupakan pelajaran berharga bagi BUM Desa saat ini.

Saat ini BUM Desa tengah menjadi isu penting bagi pemerintah, pegiat desa maupun perusahaan. Berdasarkan pengamatan lapangan maupun sharing pembelajaran di berbagai forum selama ini, upaya-upaya pengembangan BUM Desa masih menghadapi berbagai macam kelemahan, ancaman dan rendahnya kapasitas. Pertama, penataan kelembagaan desa belum berjalan secara maksimal sehingga BUM Desa pun belum diinstitusionalisasikan dalam format kepemerintahan dan perekonomian desa. Kedua, keterbatasan kapasitas sumber daya manusia di desa untuk mengelola dan mengembangkan BUM Desa yang akuntabel dan berkinerja baik. Ketiga, rendahnya inisiatif lokal untuk menggerakkan potensi ekonomi lokal bagi peningkatan kesejahteraan sosial dan ekonomi warga desa. Keempat, belum berkembangnya proses konsolidasi dan kerjasama antar stakeholders untuk mewujudkan BUM Desa sebagai patron ekonomi yang berperan memajukan ekonomi kerakyatan. Kelima, kurangnya responsivitas pemerintah daerah untuk menjadikan BUM Desa sebagai program unggulan untuk memberdayakan desa dan kesejahteraan masyarakat (Eko, 2013).

Desa tidak identik dengan Pemerintah Desa dan kepala desa, namun meliputi pemerintahan lokal dan sekaligus mengandung masyarakat, yang keseluruhannya membentuk kesatuan hukum. Konstruksi ini juga membawa perbedaan antara aspek kajian BUM Desa dengan Badan Usaha Milik Negara/Daerah (BUMN/BUMD) yang merupakan badan usaha yang berperan sebagai alat intervensi 
pemerintah pada tataran perekonomian nasional atau daerah.

Dalam studi PKDOD LAN (2016), ditemukan bahwa insiatif pembentukan BUM Desa lebih banyak muncul dari pihak luar desa, di mana seharusnya hadir bersamaan di internal desa (pemerintah desa dan masyarakat) dalam musyawarah desa. Kehadiran BUM Desa seringkali bukan dilatarbelakangi oleh kondisi dan permasalahan yang ada di desa. Penyelenggaraan musyawarah desa dalam pembentukan BUM Desa hanya sebatas memenuhi persyaratan administratif semata. PKDOD juga memetakan letak kekeliruan pendekatan intervensi. Pertama, pembentukan BUM Desa yang serentak dan seragam memperlihatkan lompatan cepat, bahkan instan, yang tidak diawali dengan penjajagan kelayakan kondisional (termasuk syarat-syarat pembentukan BUM Desa). Kedua, pemberian bantuan modal dari atas secara merata (bagi rata) ke seluruh BUM Desa cenderung tidak memberikan insentif, melainkan disinsentif terhadap kesiapan dan prakarsa lokal. Ketiga, komitmen politik dari atas berjalan jauh lebih cepat ketimbang konsolidasi pilar sosial (pembelajaran, kewirausahaan, swadaya, kepercayaan dan solidaritas) di level lokal.

Pendirian BUM Desa tidaklah sebatas memenuhi target pembangunan semata. Kehadirannya harus dibarengi dengan pembinaan untuk mengembangkan potensi yang dimilikinya. Studi PKDOD LAN (2016) memperlihatkan bahwa pembinaan yang dilakukan pemerintah supra desa (kabupaten/provinsi) tidak dilakukan secara bertahap dan teratur. Jika pun ada pembinaan hanya dalam rangka menjalankan kegiatan supra desa. Dapat dikatakan, BUM Desa berjalan sendiri dalam usahanya.

\section{Menakar Disain Tata Kelola Ekonomi Desa}

Undang-Undang Desa mengkonstruksikan desa sebagai organisasi campuran (hybrid) antara masyarakat berpemerintah (self governing community) dengan pemerintah lokal (local self government), di mana desa memiliki otonomi dan kewenangan dalam perencanaan, pelayanan publik, dan keuangan. Maka desa bukan lagi penunggu instruksi dari supra desa (kecamatan, kabupaten, provinsi, dan pusat). Untuk itu, tumpuan dinamika kehidupan desa sangat bergantung pada partisipasi masyarakat dalam mendorong terbangunnya kesepakatan pengelolaan desa, mampu menumbuhkan dan mengembangkan nilai sosial, budaya, ekonomi, dan pengetahuan.

Pembangunan desa dapat ditingkatkan melalui pengembangan potensi perekonomian desa dan menjadi wadah bersama masyarakat desa dalam membangun diri dan lingkungannya secara mandiri dan partisipatif. Dalam UU Desa disebutkan bahwa pembangunan desa bertujuan untuk meningkatkan kualitas hidup manusia serta penanggulangan kemiskinan, melalui penyediaan pemenuhan kebutuhan dasar, pembangunan sarana dan prasarana, pengembangan potensi ekonomi lokal, serta pemanfaatan sumber daya alam dan lingkungan secara berkelanjutan, dengan mengedepankan kebersamaan, kekeluargaan, dan kegotongroyongan guna mewujudkan pengarusutamaan perdamaian dan keadilan sosial.

Dalam rangka mengembangkan potensi ekonomi desa dan meningkatkan kesejahteraan masyarakat, dalam pasal 87 UU Desa tersebut menyatakan bahwa pemerintah desa dapat membentuk Badan Usaha Milik Desa (BUM Desa). Kelembagaan BUM Desa diharapkan dapat memberikan ruang pengambilan peran negara melalui pemerintah desa untuk mengelola sumber daya alam yang dimiliki desa dan bidang produksi yang penting bagi desa dan yang menguasai hajat hidup warga desa. 
Tabel 1. BUM Desa Tirta Mandiri di Desa Ponggok-Klaten

dan BUM Desa Panggung Lestari di Desa Panggungharjo-Bantul

\begin{tabular}{|c|c|c|c|}
\hline No & $\begin{array}{l}\text { Nama } \\
\text { BUM } \\
\text { Desa }\end{array}$ & Lokus & $\begin{array}{c}\text { Deskripsi Jenis } \\
\text { Usaha }\end{array}$ \\
\hline \multirow[t]{4}{*}{1.} & \multirow[t]{4}{*}{$\begin{array}{l}\text { Tirta } \\
\text { Mandiri }\end{array}$} & \multirow[t]{4}{*}{$\begin{array}{l}\text { Desa Ponggok, } \\
\text { Kecamatan } \\
\text { Polanharjo, } \\
\text { Kabupaten } \\
\text { Klaten-Jawa } \\
\text { Tengah }\end{array}$} & $\begin{array}{l}\text { Jenis Usaha: } \\
\text { sumber daya } \\
\text { lokal (rekreasi } \\
\text { kolam } \\
\text { renang/Umbul } \\
\text { Ponggok, } \\
\text { layanan Jasa } \\
\text { keuangan, } \\
\text { fasilitas Air } \\
\text { bersih, hingga } \\
\text { usaha } \\
\text { persewaan) }\end{array}$ \\
\hline & & & $\begin{array}{l}\text { Kelembagaan: } \\
\text { Pemerintah } \\
\text { Desa dan } \\
\text { Pengelola BUM } \\
\text { Desa }\end{array}$ \\
\hline & & & $\begin{array}{l}\text { Kerjasama } \\
\text { Kemitraan: PT. } \\
\text { Bank BNI } 46\end{array}$ \\
\hline & & & $\begin{array}{l}\text { Omset: Rp } 2 \mathrm{M} \\
\text { per bulan }\end{array}$ \\
\hline \multirow[t]{4}{*}{2.} & \multirow[t]{4}{*}{$\begin{array}{l}\text { Panggung } \\
\text { Lestari }\end{array}$} & \multirow[t]{4}{*}{$\begin{array}{l}\text { Desa } \\
\text { Panggungharjo, } \\
\text { Kecamatan } \\
\text { Sewon, } \\
\text { Kabupaten } \\
\text { Bantul- } \\
\text { Provinsi } \\
\text { Daerah } \\
\text { Istimewa } \\
\text { Yogyakarta }\end{array}$} & $\begin{array}{l}\text { Jenis Usaha: } \\
\text { pelayanan } \\
\text { publik } \\
\text { (pengolahan } \\
\text { sampah, limbah } \\
\text { rumah tangga, } \\
\text { minyak } \\
\text { nyamplung } \\
\text { untuk kosmetik, } \\
\text { inisiasi agro } \\
\text { untuk } \\
\text { kebutuhan } \\
\text { pakan sehat dan } \\
\text { produksi pupuk } \\
\text { organik) }\end{array}$ \\
\hline & & & $\begin{array}{l}\text { Kelembagaan: } \\
\text { Pemerintah } \\
\text { Desa dan } \\
\text { Pengelola BUM } \\
\text { Desa }\end{array}$ \\
\hline & & & \begin{tabular}{l}
\multicolumn{2}{l}{ Kerjasama: } \\
Dinas Sosial \\
Prov. DIY dan \\
PT. \\
Jakarta
\end{tabular} \\
\hline & & & $\begin{array}{l}\text { Omset: } \operatorname{Rp} 70 \\
\text { juta per bulan }\end{array}$ \\
\hline
\end{tabular}

Sumber: diolah dari berbagai sumber
Selanjutnya, dalam rangka pelaksanaan UU Desa telah dibuat aturan turunannya antara lain Peraturan Pemerintah Nomor 43 Tahun 2014 jo Peraturan Pemerintah Nomor 47 Tahun 2015 sebagai peraturan pelaksanaan undang-undang tersebut yang kemudian secara khusus BUM Desa dipayungi dan digerakkan dalam Peraturan Menteri Desa, PDT dan Transmigrasi Nomor 4 Tahun 2015 tentang Pendirian, Pengurusan dan Pengelolaan dan Pembubaran Badan Usaha Milik Desa.

Sebelum hadir Peraturan Peraturan Menteri Nomor 4 Tahun 2015, sebagian pemerintah daerah telah membentuk BUM Desa, dan pasca Peraturan Menteri Desa tersebut maka semakin banyak BUM Desa yang terbentuk. Hingga saat ini telah terbentuk 12.115 BUM Desa seperti dilansir dari situs resmi Kementerian Desa PDTT. Jumlah tersebut melampaui target sebanyak 5.000 BUM Desa pada tahun 2019 yang telah mereka tetapkan dalam Nawakerja Kementerian Desa dan Pembangunan Daerah Tertinggal dan Transmigrasi. Namun hingga saat ini belum ada data yang menunjukkan kinerja BUM Desa yang sudah terbentuk.

Pencapaian yang melampaui target tersebut, menimbulkan kerisauan yang tertuju pada keberlanjutan BUM Desa secara sosial dan ekonomi yang saat ini tengah menjamur di berbagai desa. Ada kerisauan, jangan-jangan BUM Desa akan mati suri pada tahun-tahun mendatang seperti halnya BUUD maupun KUD yang dibangun secara seragam oleh Orde Baru. Keberlanjutan BUM Desa di satu sisi dan kegagalan BUUD dan KUD disisi lain tentu merupakan pelajaran berharga bagi BUM Desa saat ini.

Saat ini BUM Desa tengah menjadi isu penting bagi pemerintah, pegiat desa maupun perusahaan. Berdasarkan pengamatan lapangan maupun sharing di berbagai forum selama ini, upaya-upaya pengembangan BUM Desa masih menghadapi berbagai macam kelemahan, ancaman dan rendahnya kapasitas. 
Pertama, penataan kelembagaan desa belum berjalan secara maksimal sehingga BUM Desa pun belum diinstitusionalisasikan dalam format kepemerintahan dan perekonomian desa. Kedua, keterbatasan kapasitas sumber daya manusia di desa untuk mengelola dan mengembangkan BUM Desa yang akuntabel dan berkinerja baik. Ketiga, rendahnya inisiatif lokal untuk menggerakkan potensi ekonomi lokal bagi peningkatan kesejahteraan sosial dan ekonomi warga desa. Keempat, belum berkembangnya proses konsolidasi dan kerjasama antar stakeholders untuk mewujudkan BUM Desa sebagai patron ekonomi yang berperan memajukan ekonomi kerakyatan. Kelima, kurangnya responsivitas Pemda untuk menjadikan BUM Desa sebagai program unggulan untuk memberdayakan desa dan kesejahteraan masyarakat (Eko, 2013, Yunanto dkk, 2014).

Desa tidak identik dengan Pemerintah Desa dan kepala desa, namun meliputi pemerintahan lokal dan sekaligus masyarakat desa, yang secara keseluruhan membentuk kesatuan hukum. Konstruksi ini juga membawa perbedaan antara aspek kajian BUM Desa dengan Badan Usaha Milik Negara/Daerah (BUMN/BUMD) yang merupakan badan usaha yang berperan sebagai alat intervensi pemerintah pada tataran perekonomian nasional atau daerah.

Dalam studi PKDOD LAN (2016), ditemukan bahwa insiatif pembentukan BUM Desa lebih banyak muncul dari pihak luar desa, dimana seharusnya hadir bersamaan di internal desa (pemerintah desa dan masyarakat) dalam musyawarah desa. Kehadiran BUM Desa seringkali bukan dilatarbelakangi oleh kondisi dan permasalahan yang ada di desa. Penyelenggaraan musyawarah desa dalam pembentukan BUM Desa hanya sebatas memenuhi persyaratan administratif semata. PKDOD juga memetakan letak kekeliruan pendekatan intervensi. Pertama, pembentukan BUM Desa yang serentak dan seragam memperlihatkan lompatan cepat, bahkan instan, yang tidak diawali dengan penjajagan kelayakan kondisional (termasuk syarat-syarat pembentukan BUM Desa). Kedua, pemberian bantuan modal dari atas secara merata (bagi rata) ke seluruh BUM Desa cenderung tidak memberikan insentif, melainkan disinsentif terhadap kesiapandan prakarsa lokal. Ketiga, komitmen politik dari atas berjalan jauh lebih cepat ketimbang konsolidasi pilar sosial (pembelajaran, kewirausahaan, swadaya, kepercayaan dan solidaritas) di level lokal.

Pendirian BUM Desa tidaklah sebatas memenuhi target pembangunan semata. Kehadirannya harus dibarengi dengan pembinaan untuk mengembangkan potensi yang dimilikinya. Studi PKDOD LAN (2016) memperlihatkan bahwa pembinaan yang dilakukan pemerintah supra desa (kabupaten/provinsi) tidak dilakukan secara bertahap dan teratur. Jika pun ada pembinaan hanya dalam rangka menjalankan kegiatan supra desa. Dapat dikatakan, BUM Desa berjalan sendiri dalam usahanya.

\section{Menakar Disain Tata Kelola Ekonomi Perdesaan}

Undang-Undang No. 6 Tahun 2014 tentang Desa mengkonstruksikan desa sebagai organisasi campuran (hybrid) antara masyarakat berpemerintah (self governing community) dengan pemerintah lokal (local self government), di mana desa memiliki otonomi dan kewenangan dalam perencanaan, pelayanan publik, dan keuangan. Maka desa bukan lagi penunggu instruksi dari supra desa (kecamatan, kabupaten, provinsi, dan pusat). Untuk itu, tumpuan dinamika kehidupan desa sangat bergantung pada partisipasi masyarakat dalam mendorong terbangunnya kesepakatan pengelolaan desa, mampu menumbuhkan dan mengembangkan nilai sosial, budaya, ekonomi, dan pengetahuan.

Pembangunan desa dapat ditingkatkan melalui pengembangan potensi perekonomian desa dan menjadi wadah bersama masyarakat desa dalam 
membangun diri dan lingkungannya secara mandiri dan partisipatif. Dalam UU Desa disebutkan bahwa pembangunan desa bertujuan untuk meningkatkan kualitas hidup manusia serta penanggulangan kemiskinan, melalui penyediaan pemenuhan kebutuhan dasar, pembangunan sarana dan prasarana, pengembangan potensi ekonomi lokal, serta pemanfaatan sumber daya alam dan lingkungan secara berkelanjutan, dengan mengedepankan kebersamaan, kekeluargaan, dan kegotongroyongan guna mewujudkan pengarusutamaan perdamaian dan keadilan sosial.

Dalam rangka mengembangkan potensi ekonomi desa dan perdesaan, serta meningkatkan kesejahteraan masyarakat, dalam pasal 87 UU Desa tersebut menyatakan bahwa pemerintah desa dapat membentuk Badan Usaha Milik Desa (BUM Desa). Kelembagaan BUM Desa diharapkan dapat memberikan ruang pengambilan peran negara melalui pemerintah desa untuk mengelola sumber daya alam yang dimiliki desa dan bidang produksi yang penting bagi desa dan yang menguasai hajat hidup warga desa.

Dalam rangka pelaksanaan UU Desa telah dibuat aturan turunannya antara lain Peraturan Pemerintah No. 43 Tahun 2014 jo Peraturan Pemerintah No. 47 Tahun 2015 sebagai peraturan pelaksanaan UU tersebut yang kemudian secara khusus BUM Desa dipayungi dan digerakkan dalam Peraturan Menteri Desa, PDTT No. 4 Tahun 2015 tentang Pendirian, Pengurusan, dan Pengelolaan dan Pembubaran BUM Desa.

Sebelum hadir Peraturan Menteri Desa PDTT No. 4 Tahun 2015, sebagian daerah telah membentuk BUM Desa, dan pasca peraturan menteri desa tersebut, maka semakin banyak BUM Desa yang terbentuk. Hingga saat ini telah terbentuk lebih dari 18.000 BUM Desa seperti dilansir dari situs resmi Kemendes PDTT. Jumlah tersebut melampaui target sebanyak 5.000 BUM Desa pada Tahun 2019 yang telah mereka tetapkan dalam Nawa Kerja Kemendes PDTT. Namun hingga saat ini belum ada data yang menunjukkan kinerja BUM Desa yang sudah terbentuk

Pencapaian yang melampaui target tersebut, menimbulkan kerisauan yang tertuju pada keberlanjutan BUM Desa secara sosial dan ekonomi yang saat ini tengah menjamur di berbagai desa. Ada kerisauan, jangan-jangan BUM Desa akan "mati suri" pada tahun-tahun mendatang seperti halnya BUUD maupun KUD yang dibangun secara seragam ole horde baru. Keberlanjutan BUM Desa di satu sisi dan kegagalan BUUD dan KUD di sisi lain tentu merupakan pelajaran berharga bagi BUM Desa saat ini.

Desa tidak identik dengan pemerintah desa dan kepala desa, namun meliputi pemerintahan lokal dan sekaligus mengandung masyarakat, yang keseluruhannya membentuk kesatuan hukum. Konstruksi ini juga membawa perbedaan antara aspek kajian BUM Desa dengan Badan Usaha Milik Negara/Daerah (BUMN/BUMD) yang merupakan badan usaha yang berperan sebagai alat intervensi pemerintah pada tataran perekonomian nasional atau daerah.

Dalam studi PKDOD ditemukan bahwa inisiatif pembentukan BUM Desa lebih banyak muncul dari pihak luar desa, di mana seharusnya hadir bersamaan di internal desa (pemerintah desa dan masyarakat) dalam musyawarah desa. Kehadiran BUM Desa seringkali bukan dilatarbelakangi oleh kondisi dan permasalahan yang ada di desa. Penyelenggaraan musyawarah desa dalam pembentukan BUM Desa hanya sebatas memenuhi persyaratan administratif semata. PKDOD juga memetakan letak kekeliruan pendekatan intervensi.

\section{Disain Tata Kelola Ekonomi Desa dan Perdesaan Melalui BUM Desa}

Mencermati program pemberdayaan ekonomi desa dan perdesaan yang telah berkembang selama ini, penulis menawarkan beberapa hal mengenai tata kelola ekonomi desa dan perdesaan sebagai berikut: 1) Mereplikasi program pemberda- 
yaan ekonomi desa yang dinilai 'berhasil' dalam upaya meningkatkan kemandirian perekonomian warga desa, misalnya program PNPM Mandiri Perdesaan yang disebut-sebut telah menuai kesuksesan di masyarakat, 2) Mengoptimalkan BUM Desa sebagai pelaksanaan amanat UU Desa dan Permendesa PDTT terkait BUM Desa dalam hal ini Permendesa PDTT No. 4 Tahun 2015, dengan cara: a) Mensosialisasikan pentingnya pembentukan BUM Desa yang didasarkan pada prinsip kebutuhan pengembangan ekonomi desa dan perdesaan, b) Membentuk BUM Bersama dalam rangka pemberdayaan ekonomi desa dalam satu kecamatan, c) BUM Desa yang dibentuk nantinya tidak boleh menjadi predator bagi usaha rakyat desa yang sudah berkembang sebelumnya.

\section{Penutup}

$\begin{array}{ccc}\text { Pendirian } & \text { BUM Desa menjadi } \\ \text { kuasa } & \text { desa, } & \text { Kementerian } \\ \text { Desa, }\end{array}$ Pembangunan Daerah Tertinggal dan Transmigrasi dan pemerintah daerah hanya berperan membantu pengembangan lebih lanjut setelah desa mendirikan BUM Desa. Pemerintah dan pemerintah daerah sebaiknya mengubah pendekatan dari intervensi ke fasilitasi, bahkan membuka kesempatan untuk melakukan rekognisi terhadap BUM Desa yang established. Dengan kata lain, memberikan rekognisi terhadap usaha desa (apa pun bentuknya) yang sudah eksis-kokoh jauh lebih penting ketimbang melakukan intervensi dengan berbagai instrumen hukum. Bagaimana pun membangkitkan dan memfasilitasi tumbuhnya gerakan ekonomi desa dan perdesaan secara emansipatoris jauh lebih penting ketimbang institusionalisasi BUM Desa secara serentak dari atas (top down).

Selain itu, pemerintah juga harus memperjelas model partisipasi yang ditawarkan dalam pengelolaan BUM Desa. Program Nawa Kerja Kementerian Desa, Pembangunan Daerah Tertinggal dan Transmigrasi untuk membentuk dan mengembangkan BUM Desa harus berbasis kebutuhan desa. Dalam konteks ini,
Pemerintah seharusnya berkoordinasi dengan pemerintah daerah, guna menginventarisasi karakter dan potensi asset desa di masing-masing wilayah. Pemahaman terhadap kondisi wilayah, karakter dan potensi aset desa akan sangat membantu dalam menyusun program dukungan pengembangan BUM Desa di masa depan.

Pemerintah dan pemerintah daerah seharusnya memfasilitasi dalam melakukan identifikasi awal terhadap embrio ekonomi (faktor-faktor produksi) desa secara jelas. Identifikasi ini sangat diperlukan untuk mencegah jangan sampai BUM Desa didirikan namun tidak melakukan kegiatan apa pun, karena tidak memahami potensi usaha yang perlu dikembangkan. Karena itu, Kementerian Desa, Pembangunan Daerah Tertinggal dan Transmigarsi dan pemerintah daerah perlu mengeluarkan kebijakan tentang panduan identifikasi potensi desa dan tahapan dalam pengembangan BUM Desa. Selain itu, Pemerintah dan pemerintah daerah juga perlu menerbitkan kebijakan yang terintegrasi dengan tugas pokok dan fungsi dari unit kerja terkait serta menyusun kategori kemandirian BUM Desa dan melakukan pemutakhiran data mengenai kondisi dari setiap BUM Desa yang ada.

\section{Daftar Pustaka}

\section{$\underline{\text { Buku }}$}

Acemoglu D., S. Johnson, dan S. Robinson. 2005. Institutions as the Fundamental Cause of Long-Run Growth in $P$. Aghion and $S$. Durlauf, (Eds.), Handbook of Economic Growth, Volume 1, Part A, Elsevier: $385-472$.

Adisasmita, Rahardjo. 2006. Pembangunan Desa dan Perkotaan. Yogyakarta: Graha Ilmu.

Arsyad, Lincoln dkk. 2011. Strategi Pembangunan Berbasis Lokal. Yogyakarta: Unit Penerbit dan Percetakan STIM YKPN.

Dixit, Avinash. 2001. On Modes of Economic Governance. Pricenton: 
Departmeny of EconomicsPricenton University.

Djankov, Simeon et.al, The Regulation of Entry, The Quarterly Journal of Economic, Vol. CXVII, 2002:1.

Eko, Sutoro bersama Tim FPPD. 2013. Policy Paper Membangun BUM Desa yang Mandiri, Kokoh dan Berkelajutan.

Gilbert, Alan \& Josef Gugler. 1996. Urbanisasi dan Kemiskinan di Dunia Ketiga. Yogyakarta: Tiara Wacana.

Kong, Tao. 2011. Governance Quality and Economic Growth. Canberra: Research School of Economic Australian University.

Kuncoro, Haryo. 2012. Apakah Tata Kelola Perekonomian Daerah di Indonesia telah Meningkat? dalam Buletin Ekonomi Moneter dan Perbankan,

Mubyarto. 1998. Pendekatan Nasional: Sistem dan Moral Ekonomi Indonesia, Jakarta: LP3ES.

North, D.C. 1981. Structure and Change in Economic History, New York, W.W. Norton.

North, D.C. 1990. Institutions, Institutional Change, and Economic Performance, UK : Cambridge University Press.

Sulistiyani, Ambar Teguh. 2004. Kemitraam dan Model-Model Pemberdayaan. Yogyakarta: Penerbit Gava Media.

Wei, Shang Jin. 2000. Local Corruption and Global Capital Flows, Brookings Papers on Economic Activity (2): 303-54.

Weiss, T.G. 2005. Governance, Good Governance, and Global Governance: Conceptual and Actual Challenges, in $\mathrm{R}$. Wilkinson, (Ed.), the Global Governance Reader, New York: Routledge.

Wibawa, Fajri Eka. 2011. Ekonomi Pedesaan. Malang: Fakultas
Keguruan dan Ilmu Pendidikan Universitas Metro.

Williamson, O. 1975. Markets and Hierarchies, Analysis and Antitrust Implications: A Study in the Economics of Internal Organization, New York: Free Press.

Williamson, O. 1985. The Economic Institutions of Capitalism: Firms, Markets, and Relational Contracting, New York: Free Press.

\section{Artikel}

Kuncoro, Haryo. 2012. Apakah Tata Kelola Perekonomian Daerah di Indonesia telah Meningkat?, Dipresentasikan pada Ulang Tahun ke -11 Asosiasi Ilmu Pemerintahan Indonesia (AIPI) di Universitas Lambung Mangkurat Banjarmasin, 9 Oktober 2012.

Masrukhin. 2000. Studi Kasus: Evaluasi Pelaksanaan Program Takesra dan Kukesra pada MAsyarakat NonIDT di Desa Dempat, Jurnal Penelitian dan Evaluasi, 2 (2):121.

Puskapol UI. 2014. Persoalan Buruh Migran di Indonesia: Identifikasi Masalah-Masalah Buruh Migran dalam http://www.puskapol.ui.ac.id/wpcontent/uploads/2014/05/factsheet-2.pdf diunduh pada tanggal 10 Mei 2017.

World Bank. 2005. Governance Indicators: 1996-2004,Washington DC: World Bank.

Yunanto dkk. 2014. Strategi Pengembangan Bumdesa sebagai Pilar Ekonomi Desa dalam http://www.keuangandesa.com/ 2015/04/strategi-pengembanganbumdes-sebagai-pilar-ekonomidesa/.

Karim, Ahmad Rizqul. 2016. dalam http://faperta.unsoed.ac.id/2016/10/ 01/bum-desa-bagi-kesejahteraanmasyarakat-desa/. 


\section{Peraturan Perundangan}

UU Nomor 6 Tahun 2014 Desa. 15 Januari 2014. Lembaran Negara Republik Indonesia Tahun 2014 Nomor 7. Jakarta.

Peraturan Pemerintah Nomor 43 Tahun 2014 Peraturan Pelaksanaan Undang-Undang Nomor 6 Tahun 2014 tentang Desa. 30 Mei 2014. Lembaran Negara Republik Indonesia Tahun 2014 Nomor 123. Jakarta.
Peraturan Menteri Desa, Pembangunan Daerah Tertinggal dan Transmigrasi Nomor 4 Tahun 2015 Pendirian, Pengurusan, Pengelolaan, dan Pembubaran Badan Usaha Milik Desa. 13 Februari 2015. Berita Negara Republik Indonesia Tahun 2015 Nomor 296. Jakarta. 